\title{
Comorbidity of Geo-Helminthes among Malaria Outpatients of the Health Facilities in Ethiopia: Systematic Review and Meta-Analysis
}

\author{
Minyahil Tadesse Boltena ${ }^{1, *,+}{ }^{(\mathbb{C}}$, Ziad El-Khatib ${ }^{2,3,+}$, Abraham Sahlemichael Kebede ${ }^{4}(\mathbb{D}$, \\ Benedict Oppong Asamoah ${ }^{5}\left(\mathbb{D}\right.$, Andualem Tadesse Boltena ${ }^{5}$, Melese Yeshambaw ${ }^{1}\left(\mathbb{D}\right.$ and Mulatu Biru ${ }^{1}$ \\ 1 Armauer Hansen Research Institute, Ministry of Health, Addis Ababa 1005, Ethiopia; \\ myeshambaw@gmail.com (M.Y.); mulatu.biru@ahri.gov.et (M.B.) \\ 2 Department of Global Public Health, Karolinska Institutet, 17177 Stockholm, Sweden; ziad.el-khatib@ki.se \\ 3 World Health Programme, Université du Québec en Abitibi-Témiscamingue (UQAT), \\ Rouyn-Noranda, QC J9X5E4, Canada \\ 4 School of Health Sciences, University of Brighton, Brighton BN1 9PH, UK; a.s.kebede@brighton.ac.uk \\ 5 Social Medicine and Global Health, Department of Clinical Sciences, Lund University, 22100 Lund, Sweden; \\ Benedict_Oppong.Asamoah@med.lu.se (B.O.A.); andy_tadesse@yahoo.com (A.T.B.) \\ * Correspondence: minyahil.tadesse@ahri.gov.et \\ + Co-first author.
}

Citation: Boltena, M.T.; El-Khatib, Z.; Sahlemichael Kebede, A.; Asamoah, B.O.; Tadesse Boltena, A.; Yeshambaw, M.; Biru, M. Comorbidity of Geo-Helminthes among Malaria Outpatients of the Health Facilities in Ethiopia: Systematic Review and Meta-Analysis. Int. J. Environ. Res. Public Health 2021, 18, 862. https:// doi.org/10.3390/ijerph18030862

Received: 30 November 2020

Accepted: 10 January 2021

Published: 20 January 2021

Publisher's Note: MDPI stays neutra with regard to jurisdictional claims in published maps and institutional affiliations.

Copyright: (c) 2021 by the authors. Licensee MDPI, Basel, Switzerland. This article is an open access article distributed under the terms and conditions of the Creative Commons Attribution (CC BY) license (https:// creativecommons.org/licenses/by/ $4.0 /)$.
Abstract: Background: Coinfection of malaria and intestinal helminths affects one third of the global population, largely among communities with severe poverty. The spread of these parasitic infections overlays in several epidemiological locations and the host shows different outcomes. This systematic review and meta-analysis determine the pooled prevalence of malaria and intestinal helminthiases coinfections among malaria suspected patients in Ethiopia. Methods: Primary studies published in English language were retrieved using appropriate search terms on Google Scholar, PubMed/MEDLINE, CINHAL, Scopus, and Embase. The Joanna Briggs Institute Meta-Analysis of Statistics Assessment and Review Instrument (JBI-MAStARI) was used for critical appraisal of studies. A pooled statistical meta-analysis was conducted using STATA Version 14.0 software. The heterogeneity and publication bias were assessed using the I2 statistics and Egger's test, respectively. Duval and Tweedie's nonparametric trim and fill analysis using the random-effect analysis. The Random effects model was used to estimate the summary prevalence of comorbidity of malaria and soil transmitted helminthiases and the corresponding 95\% confidence intervals (CI). The review protocol has registered in PROSPERO number CRD42019144803. Results: We identified ten studies ( $n=6633$ participants) in this study. The overall pooled result showed $13 \%$ of the ambulatory patients infected by malaria and intestinal helminths concurrently in Ethiopia. The pooled prevalence of Plasmodium falciparum and Plasmodium vivax, and mixed infections were 12,30 , and $6 \%$, respectively. The most common intestinal helminth parasites detected were Hookworm, Ascaris lumbricoides, and Tirchuris trichiura. Conclusions: The comorbidity of malaria and intestinal helminths causes lower hemoglobin level leading to maternal anemia, preterm delivery, and still birth in pregnant women and lactating mother. School-aged children and neonates coinfected by plasmodium species and soil transmitted helminths develop cognitive impairment, protein energy malnutrition, low birth weight, small for gestational age, and gross motor delay. The Ministry of Health of Ethiopia and its international partners working on malaria elimination programs should give more emphasis to the effect of the interface of malaria and soil transmitted helminths, which calls for an integrated disease control and prevention.

Keywords: coinfection/comorbidity; intestinal helminthiases; malaria; outpatient; Ethiopia 


\section{Background}

Various forms of coinfections occur globally, mostly among societies with high poverty indices. It is projected that more than thirty-three percent of the world's population living in the tropical and sub-tropical region is mainly infected by malaria and parasitic helminths and Sub-Saharan Africa bears the highest prevalence of Malaria and intestinal helminths comorbidity [1-3]. According to the 2019 World Health Organization (WHO) malaria report, an estimated 228 million cases and 405,000 deaths related to malaria in the year 2018 were registered, with the SSA region bearing the highest burden, with $93 \%$ of all cases $[4,5]$.

Intestinal helminth infections are the most predominant of lingering human infections and grounded on existing evidence, there are an estimated 1221 million Ascaris lumbricoides, 795 million Trichuristrichiura, 740 million Hookworms, 206.4 million Schistosoma spp. [1,6].

Various epidemiological settings have different malaria and intestinal helminthiases coinfections with the host exhibiting varying outcomes [2,7-13]. Concurrent infection from malaria and helminthes is associated with health complications in the host causing immunosuppression and reduced hemoglobin concentration resulting in anemia [14]. Women infected with soil transmitted helminthiasis are nearly five times more likely to suffer from malaria infection and pregnant mothers coinfected by malaria and geohelminths in malaria endemic regions are at higher risk of feto-maternal morbidity and mortality [12,14,15].

Pregnant women and nursing mothers, neonates and school-aged children are known to be the risk groups affected by the concomitant malaria intestinal helminthic infection [16]. Pregnant women and nursing mothers co-infected by malaria Plasmodium and geo-helminthic parasites are at higher risk for maternal anemia, preterm deliveries, and still births [17,18]. Comorbidity of Plasmodium species and soil transmitted helminthic infection causes cognitive impairment, protein energy malnutrition and mild to severe anemia in children $[19,20]$, and low birth weight, small for gestational age and gross motor outcomes in infants [21,22].

Nevertheless, how co-infections affect the epidemiology and pathogenesis of each other is still controversial [23-25] ranging from lower severity and lower incidence of malaria to higher severity of malaria in co-infections [26-39]. The fundamental cause for such different outcomes could be attributed to several factors, including variation in defining the case and design of the study, analysis of the data and interpretation, the expression of antigen cross-reactivity between co-infecting organisms and host factors [25].

According to our knowledge, there is a lack of studies on the impact of comorbidity of malaria and soil transmitted helminthes, and its prevalence and severity in Ethiopia. Therefore, this study will determine the pooled magnitude of the comorbidity of malaria and intestinal helminthiasis among the malaria outpatients in Ethiopia.

\section{Methods}

This review was registered in the Prospective International Register of Systematic Reviews (PROSPERO with number CRD42019144812) and is reported according to the MOOSE (Meta-analysis Of Observational Studies in Epidemiology) guidelines [40].

\subsection{Search Strategy and Selection of Studies}

The search strategy was aimed to locate both published and grey literature. An initial limited search of Google Scholar was undertaken to identify articles on the topic. The text words contained in the titles and abstracts of relevant articles, and the index terms used to describe the articles were used to develop a full search strategy for PubMed/Medline, EMBASE, CINHAL, Google Scholar, and Scopus to adapted for each included information source. A combination of keywords and systematic search term including all identified keywords and index terms, were: ((“"Coinfection”"[MeSH Terms] OR “Comorbidity”[MeSH Terms] OR "Intestinal helminthiasis"[Supplementary Concept]) AND "Malaria"[MeSH Terms]) OR ("Plasmodium vivax"[MeSH Terms] OR "Plasmodium falciparum"[MeSH Terms] OR "Plasmodium malariae"[MeSH Terms]) OR "Pregnant Women"[MeSH Terms]) AND ("humans"[MeSH Terms] AND “english"[Language]) AND (((("coinfection*”[Text 
Word] OR "comorbidity*"[Text Word] OR "intestinal helminthiasis*"[Text Word] OR "soil transmitted helminthiases*"[Text Word] OR "geohelminth*"[Text Word]) AND "malaria*" [Text Word]) OR "plasmodium vivax" Word] OR "plasmodium malariae*"[Text Word] OR "pregnant women*"[Text Word] OR "pregnant mother*"[Text Word]) AND ("humans"[MeSH Terms] AND “english"[Language])) used to identify studies.

The reference list of all studies selected for critical appraisal was screened for additional studies. Institution-based cross-sectional studies published in the English language were included. Literature was eligible for inclusion if they reported the magnitude of comorbidity of intestinal helminthiases among malaria outpatients in Ethiopia. Systematic reviews and studies found to have methodological flaws after a quality assessment were excluded.

Following the search, all identified citations were organized and uploaded into EndNote version 15.0 and duplicates were removed. Titles and abstracts were screened by two independent reviewers (MTB and MBS) and cross checked by a third reviewer (MY) for the assessment against the inclusion criteria for the review. Potentially relevant studies were retrieved in full including their citation details. The full text of selected citations was assessed in detail against the inclusion criteria by two reviewers (MTB and MBS) and double-checked by another independent reviewer (MY). Reasons for exclusion of full-text studies that do not meet the inclusion criteria were recorded and reported in the systematic review. Any disagreements that arise between the reviewers at each stage of the study selection process were resolved through discussion, or with a third reviewer. The results of the search were reported in full in the final systematic review and presented in a Preferred Reporting Items for Systematic Reviews and Meta-analyses (PRISMA) flow diagram Figure 1 [41].

Definition of malaria and helminthic co-infection: Clinically confirmed co-infection developed by either of the Plasmodium species and one or more of the intestinal/soil transmitted helminthes.

\subsection{Data Extraction and Management}

The authors jointly prepared and determined the data extraction tool for this study. The data were extracted from primary studies included in the review using the data extraction tool prepared by two independent reviewers. The tool included variables such as the name of the author, publication year, study design, data collection period, sample size, study area/region, age with the highest malaria infection, prevalence of Plasmodium falciparum infection, Plasmodium vivax infection, and mixed infection and magnitude of coinfection of malaria and soil transmitted helminthes. Additionally, the tool contained information on the tools used for the diagnosis of malaria and intestinal helminthiases. Two authors (MTB and MBS) were involved in the data extraction; any disagreements that arose between the reviewers were resolved through discussion, or with a third reviewer. Authors of papers were contacted to request missing or additional data if needed.

The required information from each primary study was extracted by using a format prepared in a Microsoft Excel spreadsheet. Eligible studies were critically appraised by two independent reviewers (MTB and MBS) at the study level for methodological quality in the review using standardized critical appraisal instruments from the Joanna Briggs Institute (JBI) for incidence and prevalence [42]. Authors of papers were contacted to request missing or additional data for clarification where required. Any disagreements that arose were resolved through discussion, or with a third reviewer (MY). Following the critical appraisal, studies that did not meet certain a quality threshold were excluded. This decision was based on inadequate sample size, inappropriate sampling frame, and data analysis conducted with sufficient coverage of the identified sample (Table 1). Articles were reviewed using titles, abstracts, and full text review. Studies that did not meet inclusion criteria were excluded. 


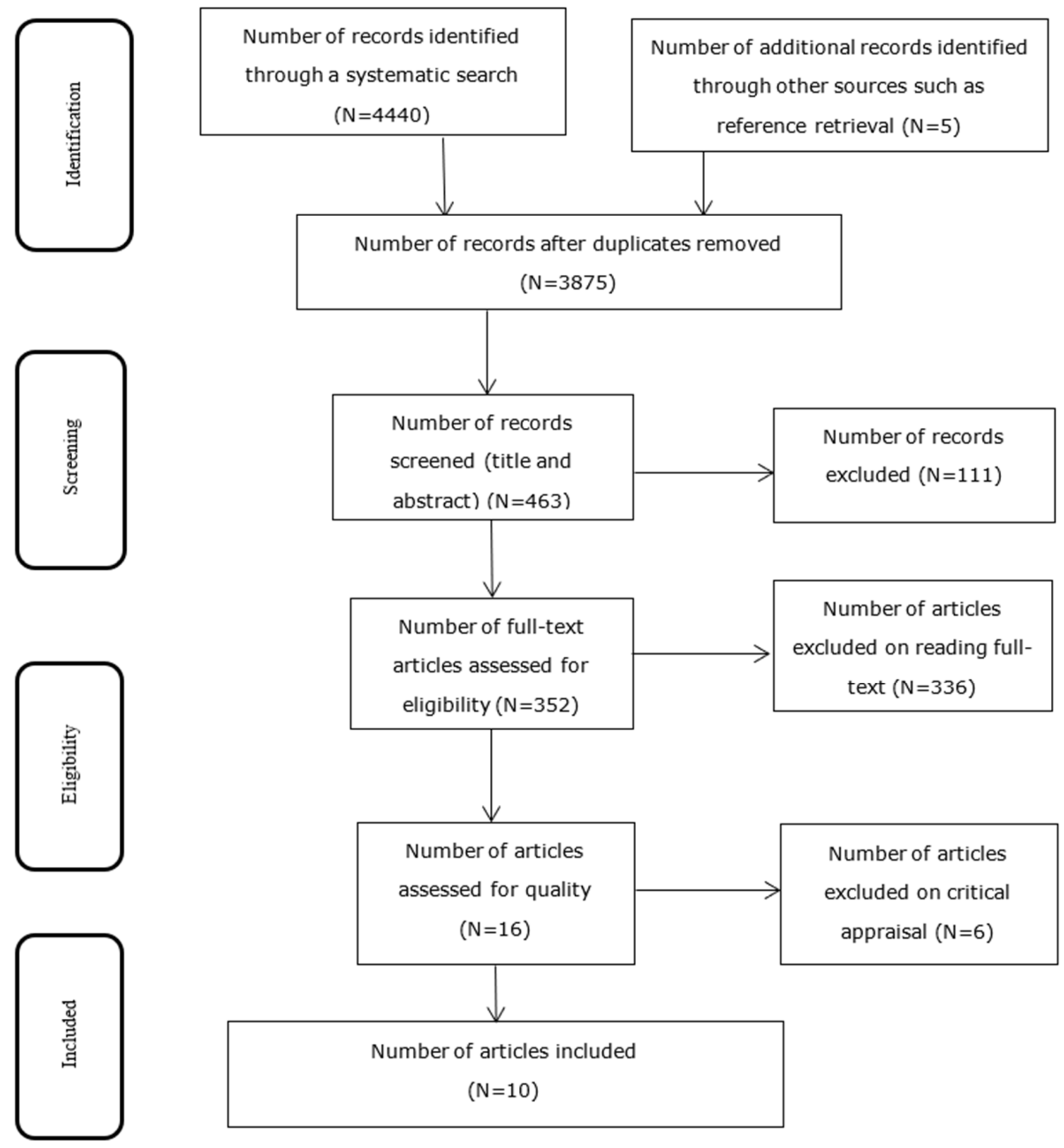

Figure 1. PRISMA flow chart diagram describing studies selected for systematic review and meta-analysis of comorbidity of geo-helminthes and malaria among outpatients in Ethiopia, 2020.

\subsection{Data Synthesis and Analysis}

Included studies were pooled in a statistical meta-analysis using STATA version 14 Effect sizes were expressed as a proportion with $95 \%$ confidence intervals around the summary estimate. Heterogeneity was assessed statistically using the standard chi-square $I^{2}$ test. A random-effects model using the double arcsine transformation approach was used. Sensitivity analyses were conducted to test decisions made regarding the included studies and to get the effect of a single study on the total estimation Figure 2. Forest plots with $95 \% \mathrm{CI}$ were compute to estimate the pooled magnitude of comorbidity of malaria 
and intestinal helminthes among outpatients in the health facilities of Ethiopia Figure 2. Visual examination of funnel plots asymmetry Figure 3 and Egger's regression tests were used to check for publication bias [43].

Table 1. The quality assessment of the studies included for the pooled estimate of comorbidity of geo-helminthes and malaria among the outpatients in Ethiopia.

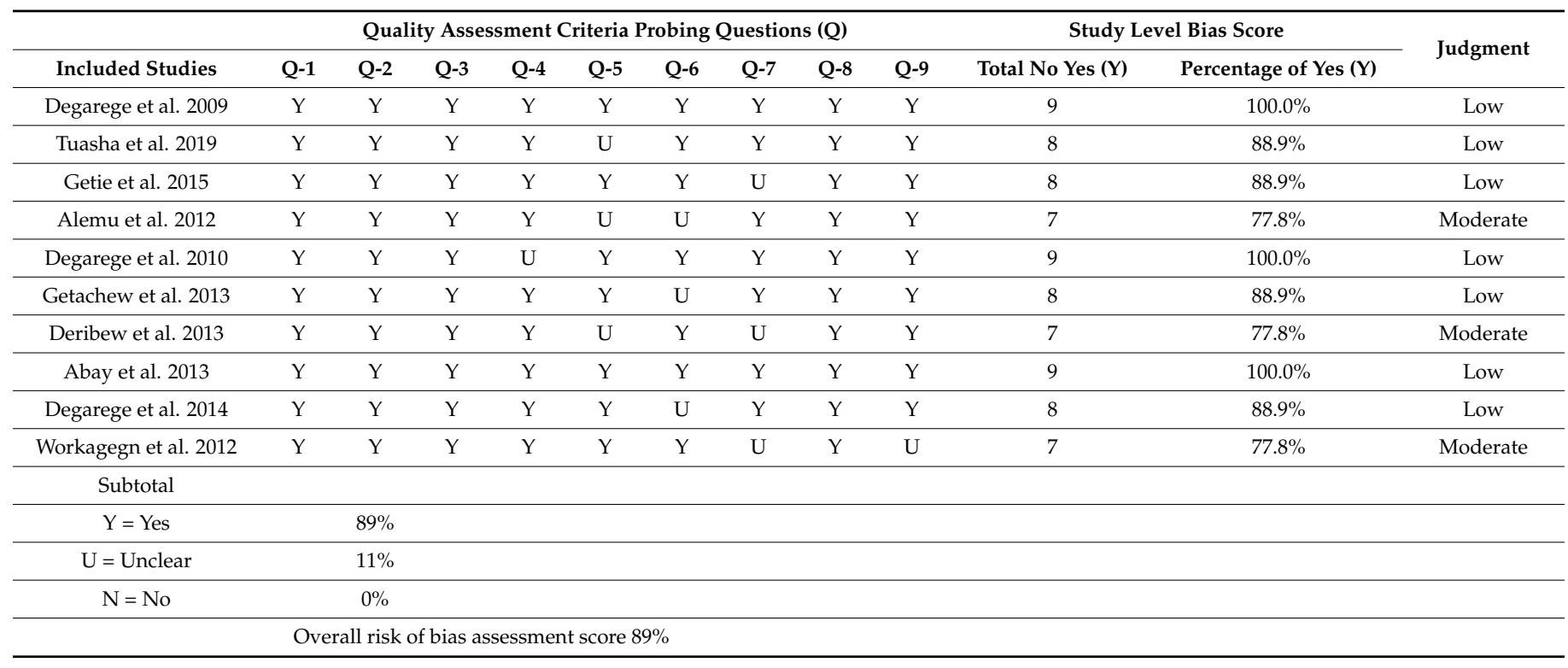

Remark: The risk of bias for each eligible study is calculated from the domain of nine criteria.

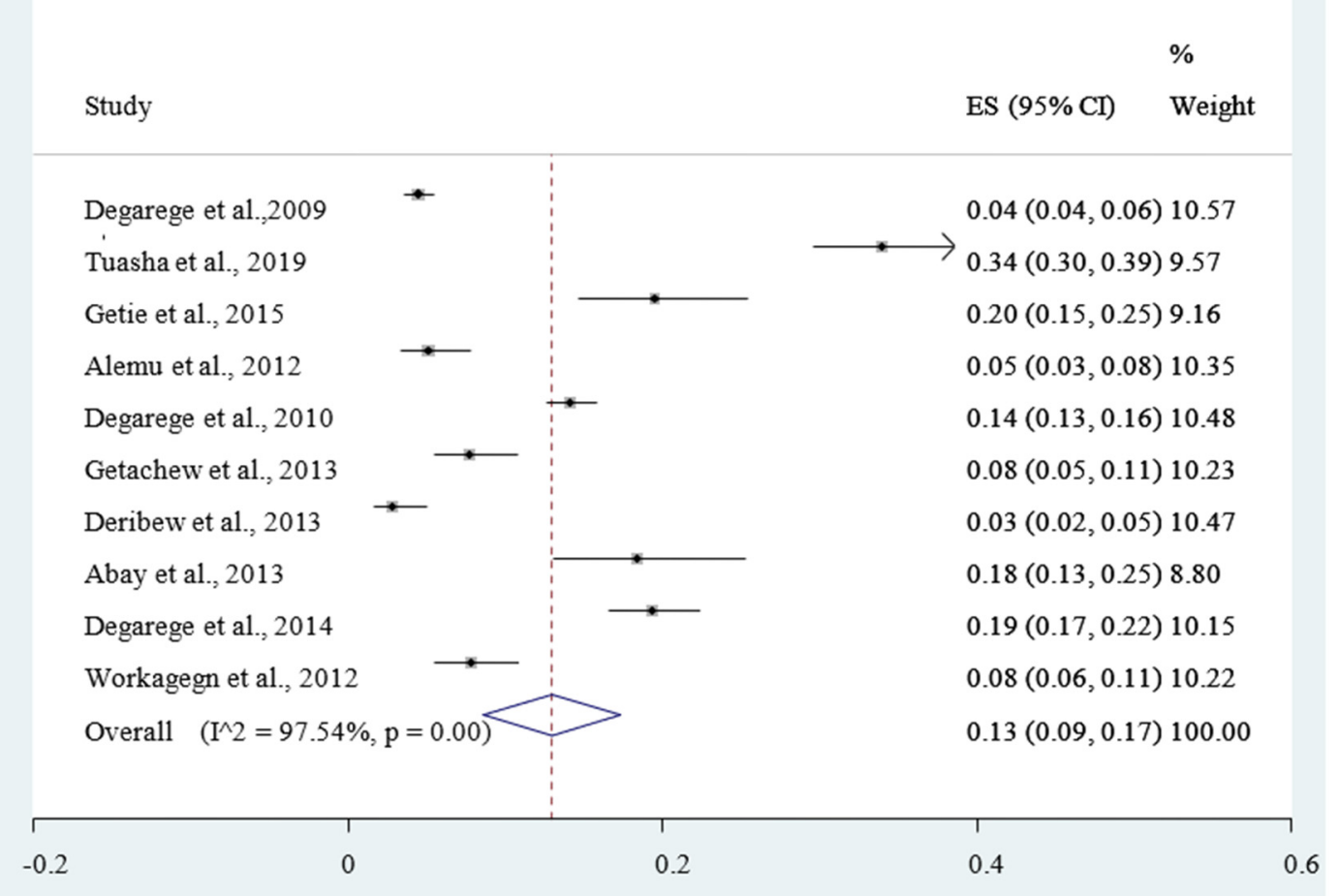

Figure 2. Forest plot of the pooled estimate of the comorbidity of geo-helminths and malaria among outpatients in Ethiopia, 2020. 


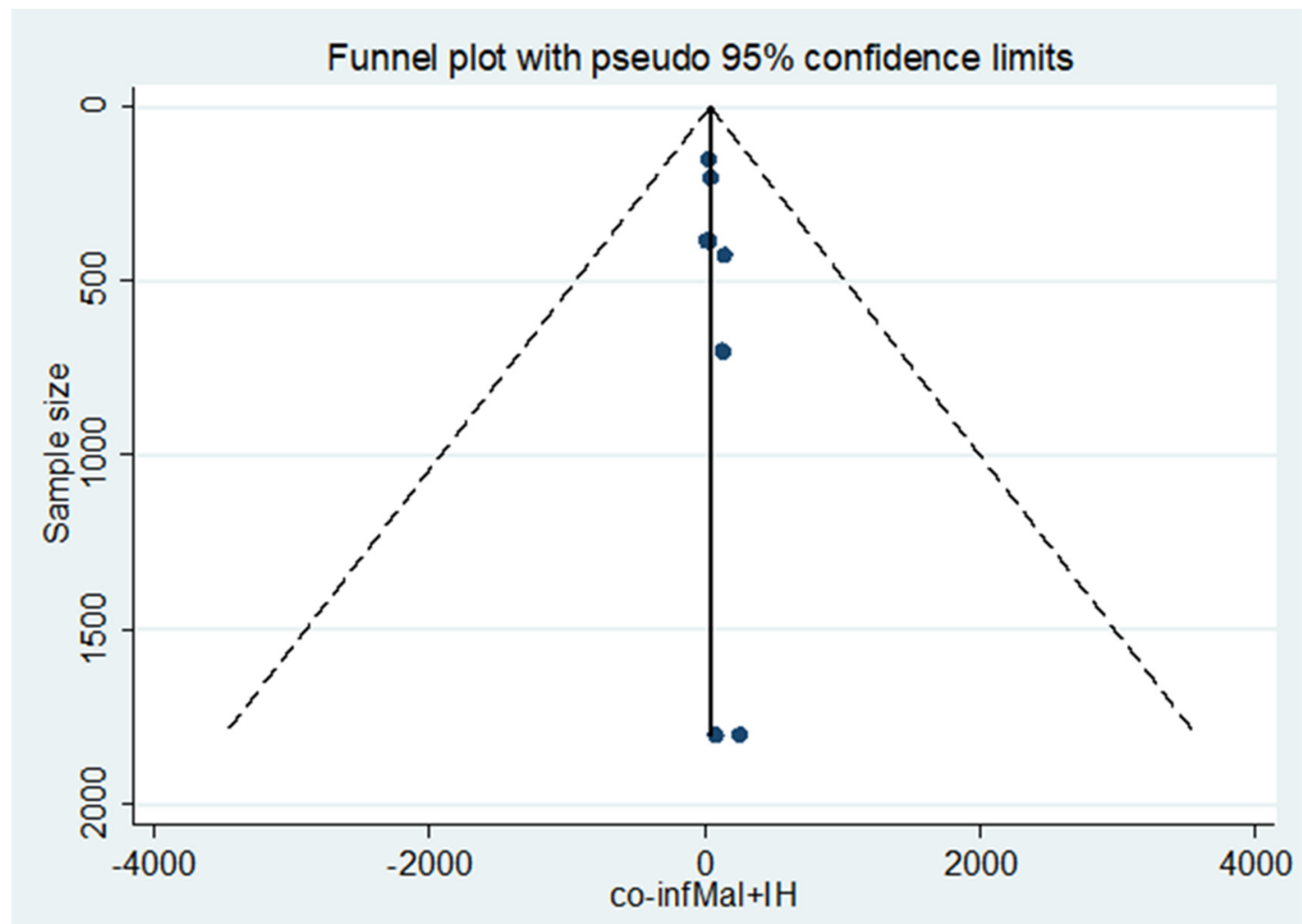

Figure 3. Funnel plot with $95 \%$ confidence limit of the comorbidity of geo-helminths and malaria among the outpatients in Ethiopia, 2020.

\section{Results}

\subsection{Search}

A total of 4445 research articles were identified by electronic search in MEDLINE/ PubMed, Google Scholar, CINAHL, EMBASE, and Scopus databases. Of these, 570 were excluded due to duplication, 3412 through review of titles and abstracts. Additionally, 352 studies found to be eligible for full-text screening, out of which 336 were excluded for not reporting the outcome variable (prevalence of comorbidity of malaria and geohelminthes among outpatients of the health facilities in Ethiopia). A total of 16 studies were eligible for quality assessment, and finally 10 studies were found to be eligible and included in the meta-analysis Figure 1.

\subsection{Included Study Characteristics}

The total sample size of the included studies in this review were 6633 patients, ranging among studies included from 152 in Oromia region [44] to 1802 in Southern Nations, Nationalities, and Peoples' Region (SNNP) [45]. Six of the included studies were from SNNP region [45-50], two studies from Amhara region [51,52], one from Afar region [53] and one from Oromia region [44]. The study design of all included studies in this review was cross-sectional (Table 2).

\subsection{Pooled Prevalence of Malaria and Intestinal Helminthiases}

The magnitude of concomitant malaria and intestinal helminthic infection varied with different geographical locations across Ethiopia, with the lowest co-infection (2.84\%) observed in Eastern Ethiopia [53] whereas the highest (55.7\%) was reported in Southern Ethiopia [47]. The pooled prevalence of $P$. falciparum, $P$. vivax, and mixed infection ( $P$. falciparum and $P$. vivax co-infection) were $12 \%$ Figure $4,30 \%$ Figure 5 , and $6 \%$ Figure 6, respectively. The $I^{2}$ test statistics result showed significant heterogeneity $\left(I^{2}=98.16 \%, p<0.001\right)$ for P. falciparum Figure $4,\left(I^{2}=99.99 \%, p<0.001\right)$ for P. vivax Figure 5 , and $\left(I^{2}=95.40 \%\right.$, 
$p<0.001)$ for mixed infection from both P. falciparum and P. vivax, with Eggers test $(p<0.001)$ for all indicates that the publication bias was not found. The Duval and Tweedie's nonparametric trim and fill analysis using the random-effect analysis was conducted to account for publication bias and heterogeneity revealed that the $I^{2}$ test result showed high heterogeneity $\left(I^{2}=99.99 \%, p<0.001\right)$ but Egger's test showed no statistically significant publication bias. The pooled magnitude of intestinal helminthic infection was 23\% Hookworm Figure 7, 25\% Ascaris lumbricoides Figure 8, and 12\% Trichuris trichiura Figure 9.

Therefore, the Duval and Tweedie nonparametric trim and fill analysis using the random-effect analysis was conducted to account for publication bias and heterogeneity. Accordingly, the pooled result of the final eligible studies for meta-analysis showed $13 \%$ ( $95 \%$ CI: $12 \%, 26 \%$ ) of malaria and intestinal helminthic comorbidity among the outpatients in Ethiopia

Figure 2, The distribution of intestinal helminthic infection was highly prevalent in SNNP region. Hookworm (37.8\%), Tirchuristrichiura (64.5\%), and Schistosoma mansoni (28.4\%) and an infection from Ascaris lumbricoides (62.1\%) were widely distributed in Amhara region (Table 2). Children aged less than five years were highly infected by malaria parasite (39\%) (Table 2). The microscopic technique and Kato-Katz thick smear testing were the two commonly used methods used to detect the malaria parasites and intestinal helminthic infection, respectively (Table 2).

Table 2. Summary characteristics of 10 studies included in the systematic review and meta-analysis of comorbidity of geo-helminthes and malaria among outpatients in Ethiopia.

\begin{tabular}{|c|c|c|c|c|c|c|c|c|c|c|c|c|}
\hline S. No & $\begin{array}{l}\text { Author, Year of } \\
\text { Publication }\end{array}$ & $\begin{array}{l}\text { Year Study } \\
\text { Conducted }\end{array}$ & Region & Study Design & $\begin{array}{l}\text { Sample } \\
\text { Size }\end{array}$ & P.f & $P . v$ & Mixed & $\begin{array}{l}\text { Co-Inf } \\
\text { Mal+ IH }\end{array}$ & $H w$ & $A l$ & $T t$ \\
\hline 1 & Degarege et al., 2009 & $\begin{array}{l}\text { November and } \\
\text { December } 2007\end{array}$ & SNNPR & Cross-sectional & 1802 & 283 & 1764 & 79 & 81 & 173 & 113.5 & 37.8 \\
\hline 2 & Tuasha et al., 2019 & $\begin{array}{c}\text { December } 2009 \text { to } \\
\text { July } 2010\end{array}$ & SNNPR & Cross-sectional & 427 & 47 & & 71 & 145 & 29 & 115 & 92 \\
\hline 3 & Getie et al., 2015 & $\begin{array}{l}\text { February to } \\
\text { May } 2013\end{array}$ & Amhara & Cross-sectional & 205 & 147 & 53 & 5 & 40 & & & \\
\hline 4 & Alemu et al., 2012 & $\begin{array}{l}\text { February to } \\
\text { March } 2011\end{array}$ & Amhara & Cross-sectional & 384 & 9 & 33 & 17 & 19.6 & 71 & 238.5 & \\
\hline 5 & Degarege et al., 2010 & $\begin{array}{l}\text { November and } \\
\text { December } 2007\end{array}$ & SNNPR & Cross-sectional & 1802 & 502 & & & 255 & 681 & 267 & 149.6 \\
\hline 6 & Getachew et al., 2013 & $\begin{array}{c}\text { August to } \\
\text { September, } 2011\end{array}$ & SNNPR & Cross-sectional & 388 & 45 & 275.8 & 51.6 & 30 & 114 & 58 & 13 \\
\hline 7 & Deribew et al., 2013 & $\begin{array}{l}\text { November to } \\
\text { December } 2008\end{array}$ & Afar & Cross-sectional & 387 & 24 & & & 11 & & & \\
\hline 8 & Abay et al., 2013 & $\begin{array}{l}\text { November to } \\
\text { December } 2009\end{array}$ & Oromia & Cross-sectional & 152 & & & & 28 & & 149.5 & 162 \\
\hline 9 & Degarege et al., 2014 & $\begin{array}{l}\text { December } 2010 \text { to } \\
\text { February } 2011\end{array}$ & SNNPR & Cross-sectional & 702 & 86 & & & 136 & & 149.5 & 162 \\
\hline 10 & Workagegn et al., 2012 & $\begin{array}{l}\text { November } 2010 \text { to } \\
\text { January } 2011\end{array}$ & SNNPR & Cross-sectional & 384 & 187 & 197 & & 30 & 138 & 107 & 63 \\
\hline
\end{tabular}

Al: Ascaris lumbricoides; Hw: Hookworm; O-Inf Mal+ IH: Coinfection of malaria and intestinal helminthes; P.f: Plasmodium falciparum; P.v: Plasmodium vivax; SNNPR: Southern Nations, Nationalities and Peoples Region; Tt: Trichuris trichiura. 


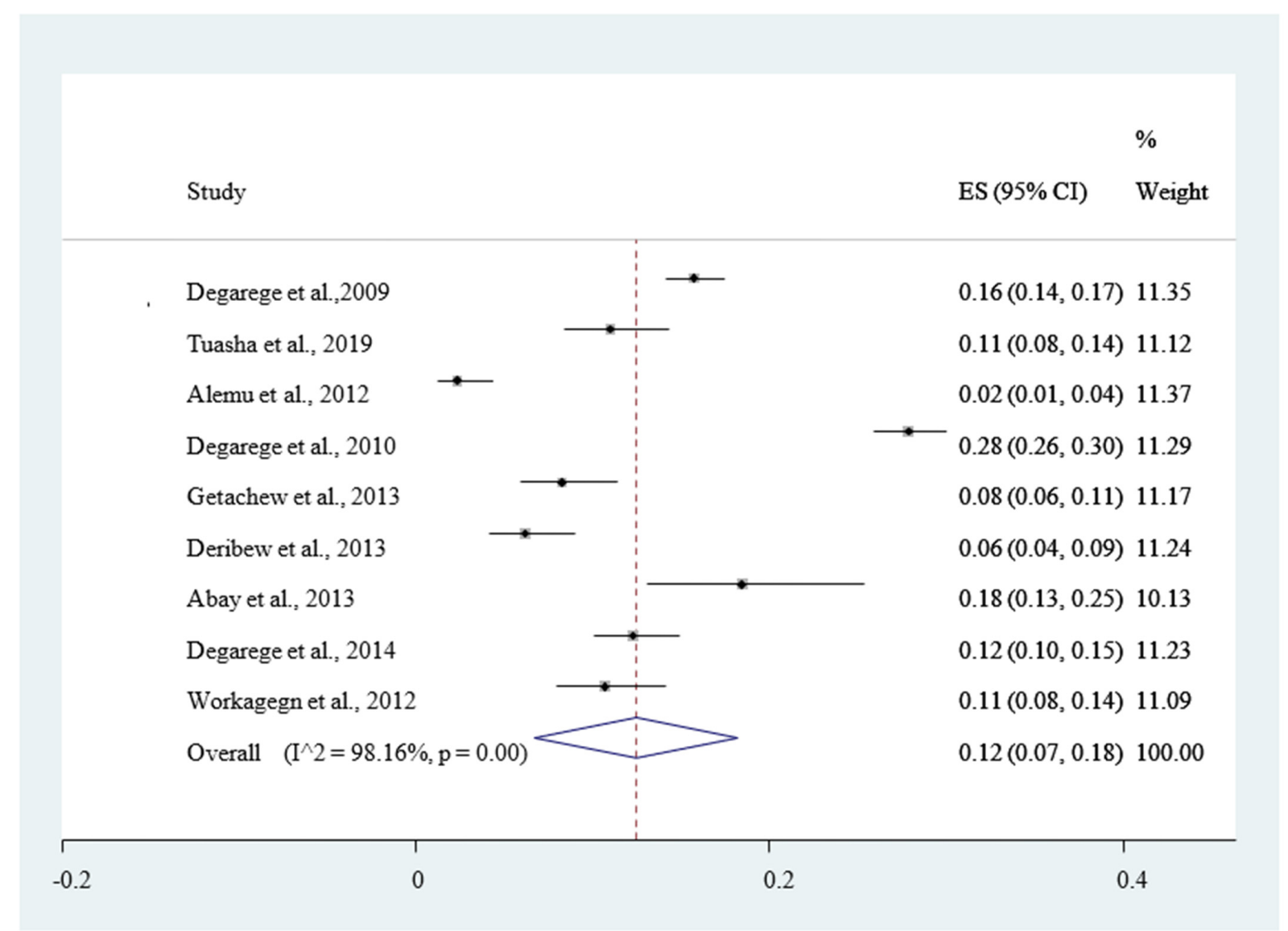

Figure 4. Forest plot of 9 studies on magnitude of Plasmodium falciparum infection among outpatients in Ethiopia, 2020.

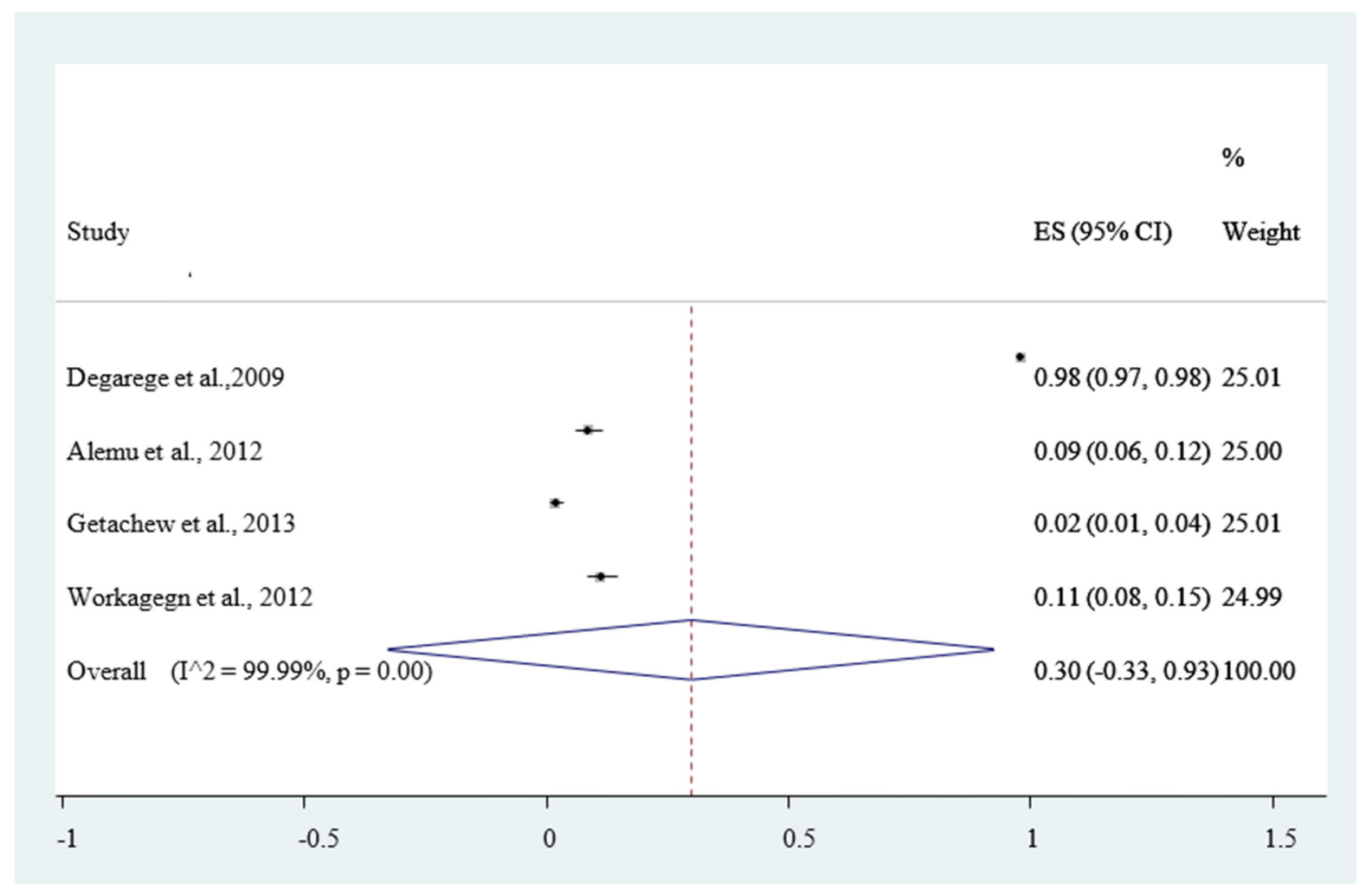

Figure 5. Forest plot of 4 studies on magnitude of Plasmodium vivax infection among out patients in Ethiopia, 2020. 


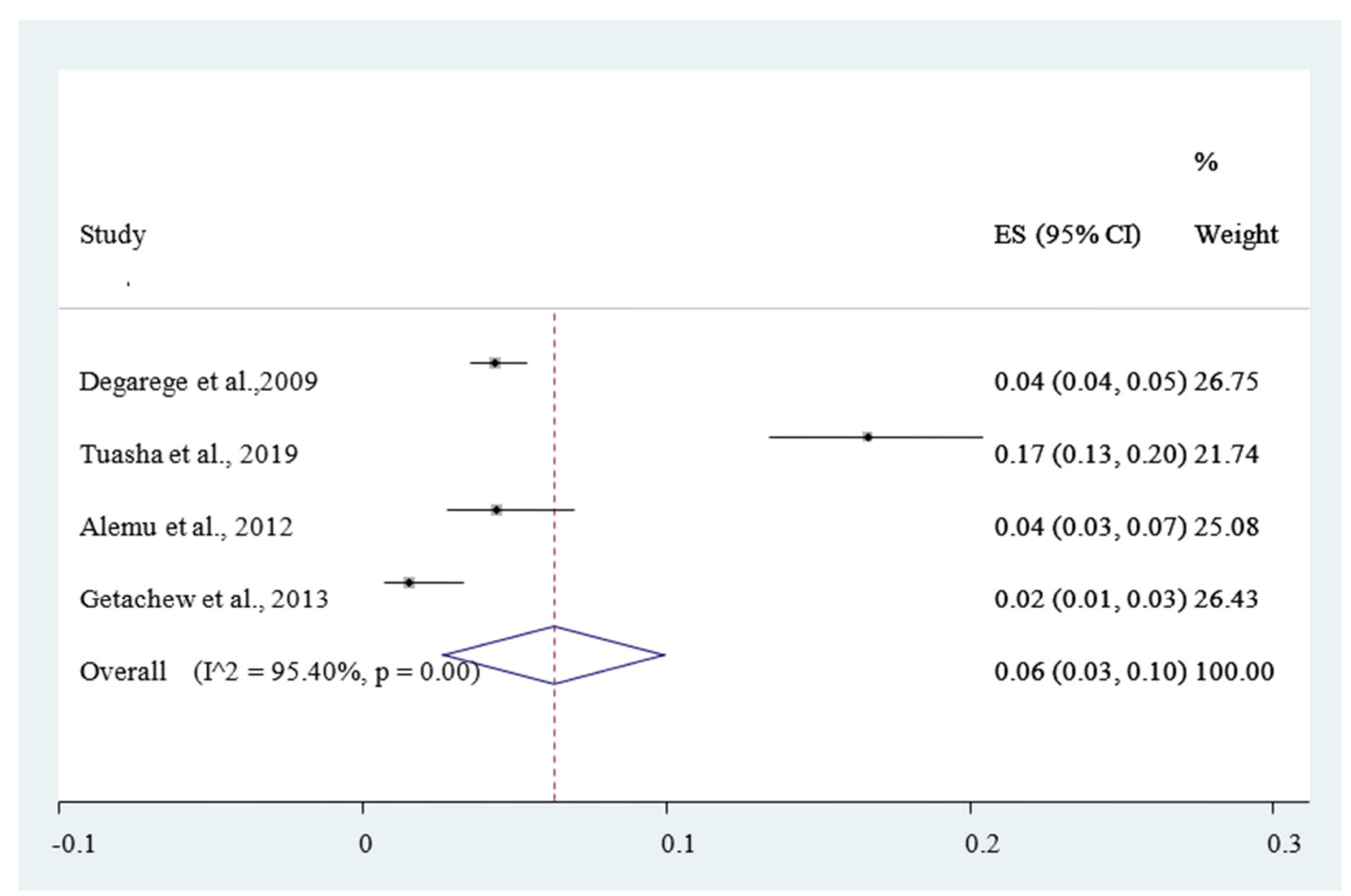

Figure 6. Forest plot of 4 studies on magnitude of Plasmodium falciparum and Plasmodium vivax mixed infection among outpatients in Ethiopia, 2020.

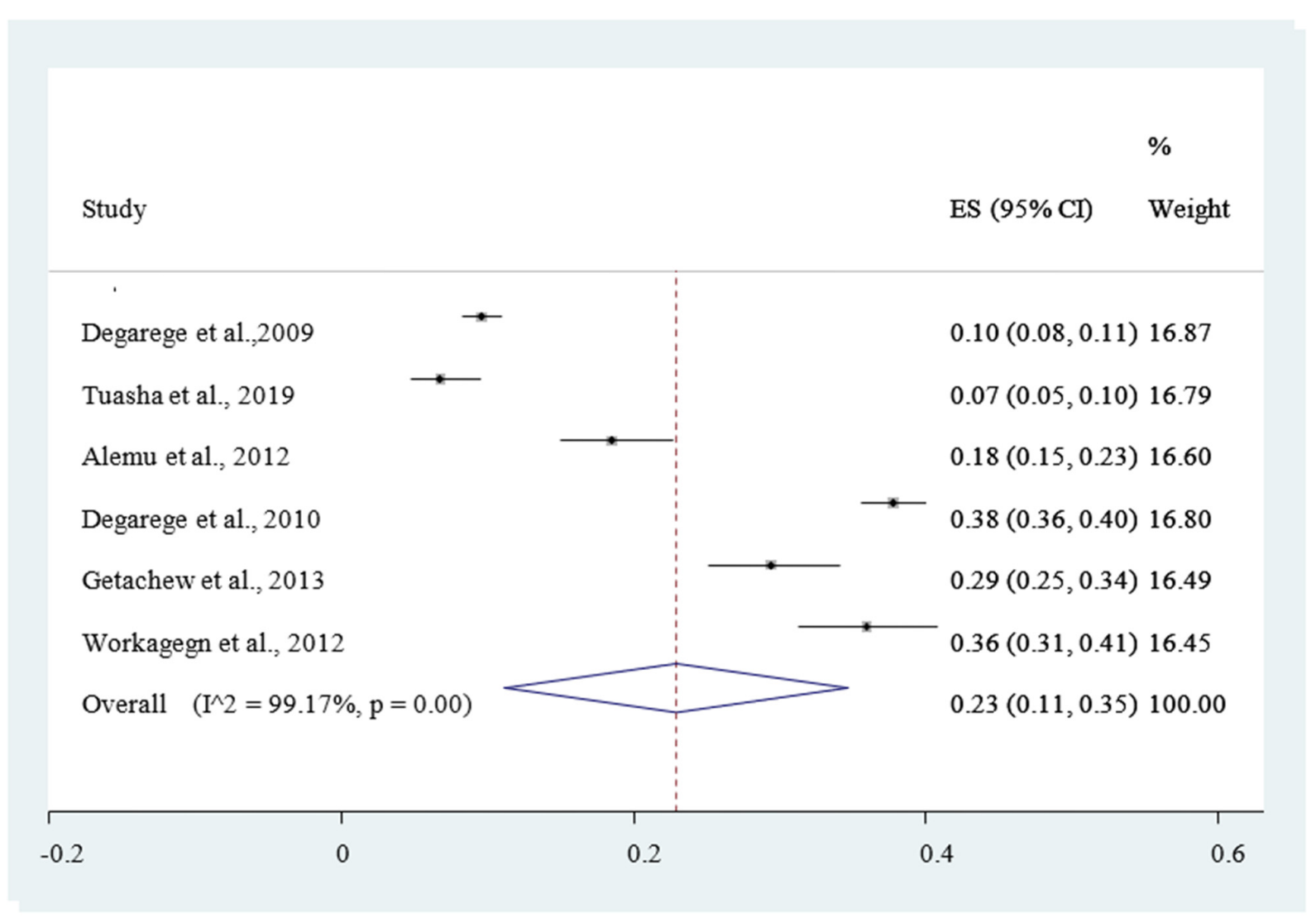

Figure 7. Forest plot of 6 studies on magnitude of Hookworm infection among outpatients in Ethiopia, 2020. 


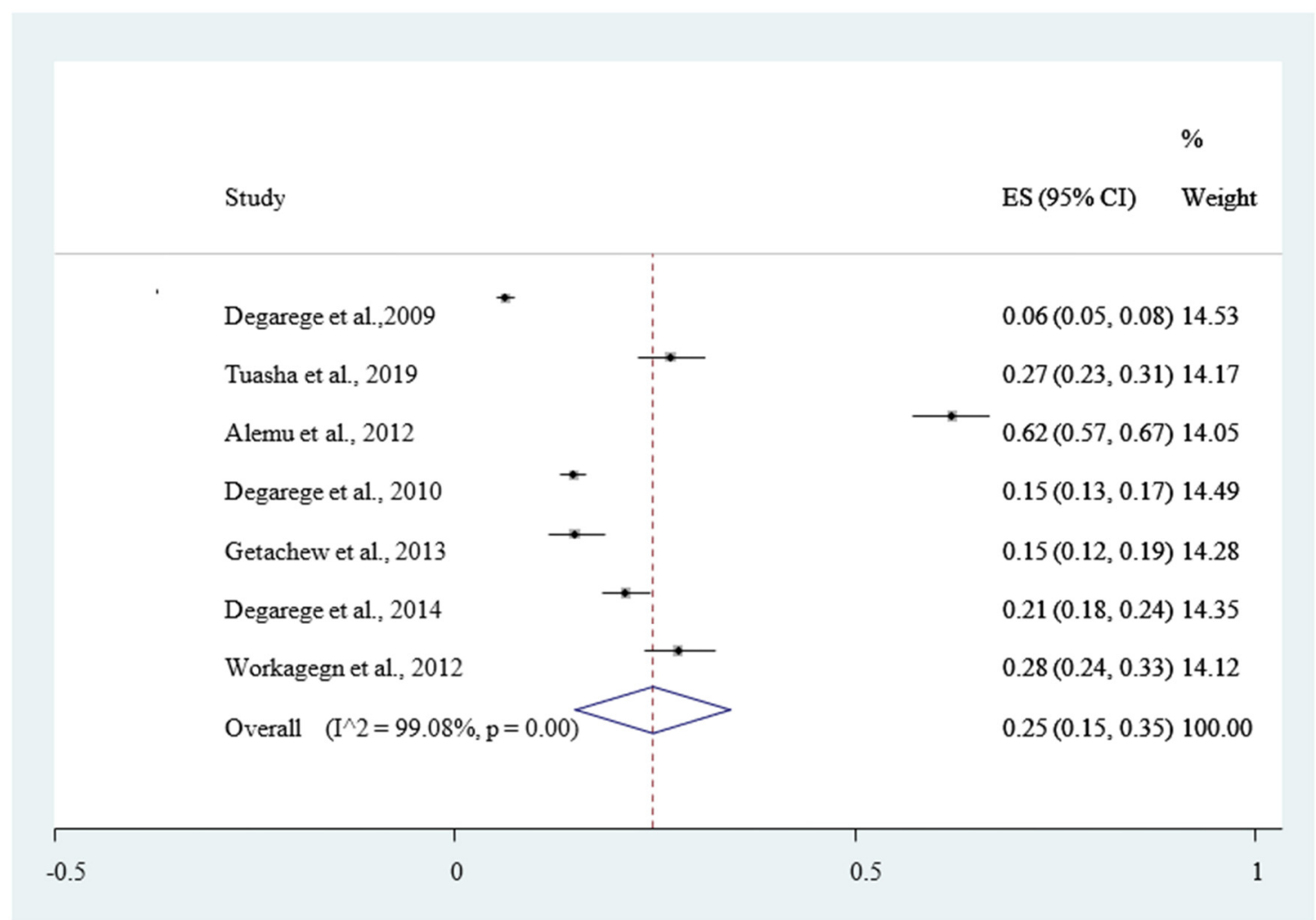

Figure 8. Forest plot of 7 studies on magnitude of Ascaris lumbricoides infection among outpatients in Ethiopia, 2020.

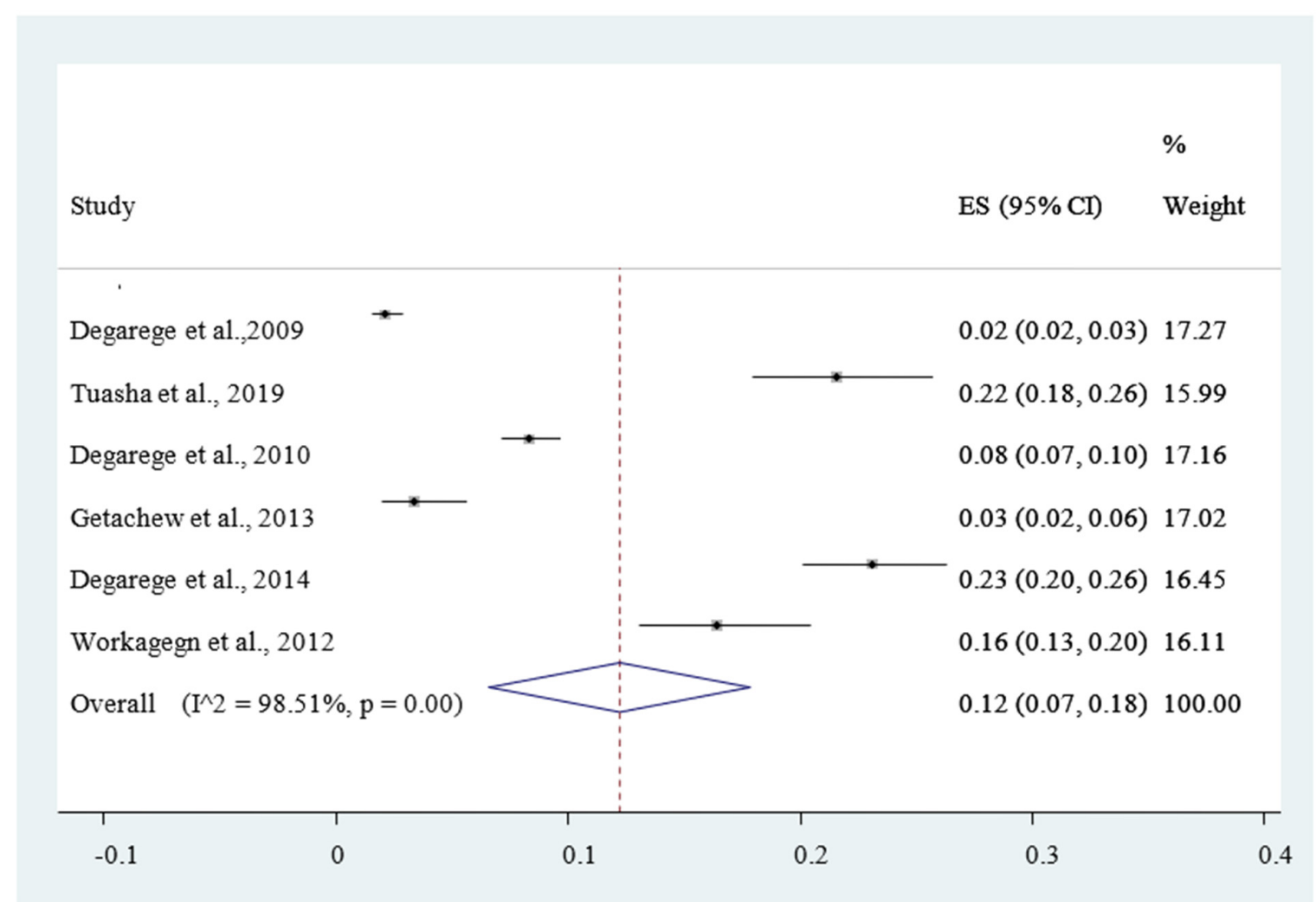

Figure 9. Forest plot of 6 studies on magnitude of Trichuris trichiura infection among outpatients in Ethiopia, 2020. 


\section{Discussion}

Data from 10 studies conducted in four different regions of Ethiopia were analyzed to determine the pooled prevalence of comorbidity of malaria and intestinal helminthiases among the outpatients. These studies reported results on the coinfection of malaria and intestinal helminths, distribution of malaria parasitemia, and intestinal helminthic infection across the regions for a total of 6633 outpatients.

The finding of this review showed that $13 \%$ (95\% CI: 9-17\%) of the ambulatory patients were infected by the malaria and intestinal helminths. This finding was higher than a study conducted in Tanzania (5\%) and Nigeria $(12 \%)[54,55]$. However, it is lower than a study conducted in peri-urban community in Nigeria (63\%) [56]. This difference could be attributed to the effective control and prevention mechanism better applied in Nigeria and Tanzania as compared to Ethiopia [54-56].

Outpatients including pregnant women and lactating mothers co-infected by Plasmodium species and geo-helminthes are at higher risk of anemia, preterm birth, and death or loss of a baby before or during delivery [57-59]. School-aged children co-infected by both malaria and helminthic parasites may develop impaired memory, deficiency in micronutrients essential for growth and development and mild to severe anemia [60,61]. Co-infection may also result in babies born weighing less than $2.5 \mathrm{~kg}$ or an infant smaller or less developed than normal for the baby's sex and gestational age and gross motor outcomes in infants $[62,63]$.

Reports of nine articles were used to estimate the pooled prevalence of Plasmodium falciparum $12 \%$ (95\% CI: 7-18\%). This finding was higher than a report from systematic review and meta- analysis where the pooled magnitude of $P$. falciparum infection was $1.4 \%$ globally [64], and lower than study conducted in Ethiopia were the pooled Plasmodium falciparum infection was $14.7 \%$ (95\% CI: 21.3, 30.4) [65].

In our report, four studies analyzed the pooled estimate of Plasmodium vivax infection. According to this study, the pooled magnitude of the P. vivax infection among the outpatients were found to be $30 \%$ (95\% CI: 33-93\%). This finding was higher than a study conducted in Ethiopia 8.7\% [65] and lower than a systematic review and meta-analysis 38\% [66]. This difference could be attributable to the parasite density and demographic variations [67].

Findings from four eligible primary studies of this review were used to analyze the pooled prevalence of the mixed Plasmodium infection, which was found to be $6 \%$ (95\% CI: $3-10 \%)$. This finding is lower than a report from systematic review and meta-analysis of Plasmodium spp. Mixed infection 9\% (95\% CI: 7.0-12.0\%) [68] and a similar study reported from Ethiopia 25.8\% (95\% CI: 21.3-30.4\%) [65].

Patients infected with Plasmodium species may develop severe complications such as severe anemia, pulmonary complications, renal failure, impaired consciousness, and jaundice. In total, six studies out of the ten eligible articles have reported to estimate the pooled prevalence of hookworm infection in the outpatients. A total of $23 \%$ (95\% CI $11-35 \%$ ) of the study participants were infected by hookworm.

This result is in agreement with a systematic review and meta-analysis in Nigeria [69]. However, this finding is higher than the finding of a systematic review and meta-analysis carried out in Asia [70] and Ethiopia [71]. Despite the differences in the pooled magnitude of hookworm infection, Ethiopia has to better practice hookworm infection controlling strategies in place.

From the eligible studies of this review, seven of them were used to estimate the pooled magnitude of intestinal helminthic infection from Ascaris lumbricoides 25\% (95\% CI 15-35\%). This result is in agreement with a report of systematic review from Asia [70] is higher than a global prevalence of Ascaris lumbricoides 17\% [95\% CI 13-21\%] [72] and a study conducted in Bangladesh 23\% [73]. This variation could be attributable to the poor performance of water and sanitation program and inadequate health education service at the community level in Ethiopia. 
According to this study, the pooled prevalence of Trichuristrichiura were found to be $12 \%$ (95\% CI 7-18\%). This finding is higher than a national estimate (5.9\%) [74] and lower than the finding a systematic review conducted in South Asia and South East Asia [75].

\section{Conclusions}

The comorbidity of malaria and intestinal helminthes causes lower hemoglobin leading to maternal anemia, preterm delivery and still birth in pregnant women. School-aged children and neonates co-infected by Plasmodium species and soil transmitted helminthes may develop cognitive impairment, protein energy malnutrition, low birth weight, small for gestational age, and gross motor delay. The Ministry of Health of Ethiopia and its international partners working on malaria elimination programs should give more emphasis to the effect of the interface of malaria and soil transmitted helminths, which calls for an integrated disease control and prevention.

Author Contributions: M.T.B., M.B. and A.S.K.; was involved in a principal role in the conception of ideas, developing methodologies, and writing the article. M.Y., A.T.B., B.O.A. and Z.E.-K. participated in the analysis, interpretation and writing. A.T.B. and Z.E.-K. involved in proofreading and writing. All authors have read and agreed to the published version of the manuscript.

Funding: This research received no external funding.

Institutional Review Board Statement: Not applicable.

Informed Consent Statement: Not applicable.

Data Availability Statement: The datasets during and/or analyzed during the current study are available from the corresponding author on reasonable request.

Acknowledgments: The Ethiopian Public Health Institute (EPHI) and The Joanna Briggs Institute (JBI), for providing the opportunity to attend the comprehensive systematic review training, and The Armauer Hansen Research Institute for enabling us and creating access to the databases.

Conflicts of Interest: The authors declare no conflict of interest.

$\begin{array}{ll}\text { Abbreviations } & \\ \text { AHRI } & \text { Armauer Hansen Research Institute } \\ \text { EPHI } & \text { Ethiopian Public Health Institute } \\ \text { JBI } & \text { The Joanna Briggs Institute } \\ \text { JBI-MAStARI } & \text { The Joanna Briggs Institute Meta-Analysis of Statistical Assessment and Review Instrument } \\ \text { LMICs } & \text { Low- and Middle-Income Countries } \\ \text { MOH } & \text { Ministry of Health } \\ \text { PRISMA } & \text { Preferred Reporting Items for Systematic Reviews and Meta-analyses } \\ \text { PROSPERO } & \text { International Prospective Registry of Systematic Reviews } \\ \text { SDG } & \text { Sustainable Development Goal } \\ \text { SNNPR } & \text { Southern Nations Nationalities and Peoples Region } \\ \text { STH } & \text { Soil Transmitted Helminthiases } \\ \text { SSA } & \text { Sub-Saharan Africa } \\ \text { WHO } & \text { The World Health Organization }\end{array}$

\section{References}

1. De Silva, N.R.; Brooker, S.; Hotez, P.J.; Montresor, A.; Engels, D.; Savioli, L. Soil-transmitted helminth infections: Updating the global picture. Trends Parasitol. 2003, 19, 547-551. [CrossRef] [PubMed]

2. Njunda, A.L.; Fon, S.G.; Assob, J.C.; Nsagha, D.S.; Kwenti, T.D.; Kwenti, T.E. Coinfection with malaria and intestinal parasites, and its association with anaemia in children in Cameroon. Infect. Dis. Poverty 2015, 4, 43. [CrossRef] [PubMed]

3. Kinung'hi, S.M.; Magnussen, P.; Kaatano, G.M.; Kishamawe, C.; Vennervald, B.J. Malaria and helminth co-infections in school and preschool children: A cross-sectional study in Magu district, north-western Tanzania. PLoS ONE 2014, 9, e86510. [CrossRef] [PubMed]

4. The World Health Organization (WHO). The "World Malaria Report 2019"; World Health Organization: Geneva, Switzerland, 2020; Available online: https://apps.who.int/iris/bitstream/handle/10665/330011/9789241565721-eng.pdf (accessed on 4 August 2020). 
5. Makenga, G.; Menon, S.; Baraka, V.; Minja, D.T.; Nakato, S.; Delgado-Ratto, C.; Francis, F.; Lusingu, J.P.; Van Geertruyden, J.P. Prevalence of malaria parasite aemia in school-aged children and pregnant women in endemic settings of sub-Saharan Africa: A systematic review and meta-analysis. Parasite Epidemiol. Control 2020, 11, e00188. [CrossRef]

6. The World Health Organization (WHO). Schistosomiasis. Available online: https://www.who.int/news-room/factsheets/detail/ schistosomiasis (accessed on 26 July 2020).

7. Efunshile, A.M.; Olawale, T.; Stensvold, C.R.; Kurtzhals, J.A.L.; König, B. Epidemiological study of the association between malaria and helminth infections in Nigeria. Am. J. Trop. Med. Hyg. 2015, 92, 578-582. [CrossRef]

8. Simon, B.; Willis, A.; Rachel, P.; Benson, E.; Sian, E.C.; Robert, W.S.; Peter, J.H. Epidemiology of plasmodium-helminth co-infection in Africa: Population at risk, potential impact on anemia and prospects for combining control. Am. J. Trop. Med. Hyg. 2007, 77, 88-98.

9. Luxemburger, C.; Kyaw, L.T.; White, N.J.; Webster, H.K.; Kyle, D.E.; Maclankirri, L.; Chongsuphajaisiddhi, T.; Nosten, F. The epidemiology of malaria in a Karen population on the western border of Thailand. Trans. R. Soc. Trop. Med. Hyg. 1996, 90, 105-111. [CrossRef]

10. Degarege, A.; Legesse, M.; Medhin, G.; Animut, A.; Erko, B. Malaria and related outcomes in patients with intestinal helminths: A cross-sectional study. BMC Infect. Dis. 2012, 12, 291. [CrossRef]

11. Mulu, A.; Legesse, M.; Erko, B.; Belyhun, Y.; Nugussie, D.; Shimelis, T.; Kassu, A.; Elias, D.; Moges, B. Epidemiological and clinical correlates of malaria-helminth co-infections in Southern Ethiopia. Malar. J. 2013, 12, 227. [CrossRef]

12. Adedoje, A.; Tijani, B.D.; Akanbi, A.A., II; Ojurongbe, T.A.; Adeyeba, O.A.; Ojurongbe, O. Co-endemicity of Plasmodium falciparum and intestinal helminthes infection in school aged children in rural communities of Kwara state in Nigeria. PLoS Negl. Trop. Dis. 2015, 9, e0003940. [CrossRef]

13. Spiegel, A.; Tall, A.; Raphenon, G.; Trape, J.-F.; Druilhe, P. Increased frequency of malaria attacks in subjects co-infected by intestinal worms and Plasmodium falciparum malaria. Trans. R. Soc. Trop. Med. Hyg. 2003, 97, 198-199. [CrossRef]

14. Akinbo, F.O.; Okaka, C.E.; Omoregie, R. Prevalence of intestinal parasitic infections among HIV patients in Benin City, Nigeria. Libyan J. Med. 2010, 5. [CrossRef] [PubMed]

15. Yatich, N.J.; Yi, J.; Agbenyega, T.; Turpin, A.; Rayner, J.C.; Stiles, J.K.; Ellis, W.O.; Funkhouser, E.; Ehiri, J.E.; Williams, J.H.; et al. Malaria and intestinal helminth co-infection among pregnant women in Ghana: Prevalence and risk factors. Am. J. Trop. Med. Hyg. 2009, 80, 896-901. [CrossRef] [PubMed]

16. Ndibazza, J.; Webb, E.L.; Lule, S.; Mpairwe, H.; Akello, M.; Oduru, G.; Kizza, M.; Akurut, H.; Muhangi, L.; Magnussen, P.; et al. Associations between maternal helminth and malaria infections in pregnancy and clinical malaria in the offspring: A birth cohort in entebbe, Uganda. J. Infect. Dis. 2013, 208, 2007-2016. [CrossRef]

17. Wanyonyi, W.A.; Mulambalah, C.S.; Mulama, D.H.; Omukunda, E.; Siteti, D.I. Malaria and geohelminthiasis coinfections in expectant women: Effect on maternal health and birth outcomes in a malaria endemic region in Kenya. J. Parasitol. Res. 2018, 2018, 2613484. [CrossRef]

18. Yatich, N.J.; Jolly, P.E.; Funkhouser, E.; Agbenyega, T.; Rayner, J.C.; Ehiri, J.E.; Turpin, A.; Stiles, J.K.; Ellis, W.O.; Jiang, Y.; et al. The effect of malaria and intestinal helminth coinfection on birth outcomes in Kumasi, Ghana. Am. J. Trop. Med. Hyg. 2010, 82, 28-34. [CrossRef]

19. Ezeamama, A.E.; Friedman, J.F.; Acosta, L.P.; Bellinger, D.C.; Langdon, G.C.; Manalo, D.L.; Olveda, R.M.; Kurtis, J.D.; Mcgarvey, S.T. Helminth infection and cognitive impairment among Filipino children. Am. J. Trop. Med. Hyg. 2005, 72, 540-548. [CrossRef]

20. Mireku, M.O.; Boivin, M.J.; Davidson, L.L.; Ouédraogo, S.; Koura, G.K.; Alao, M.J.; Massougbodji, A.; Cot, M.; Bodeau-Livinec, F. Impact of helminth infection during pregnancy on cognitive and motor functions of one-year-old children. PLoS Negl. Trop. Dis. 2015, 9, e0003463. [CrossRef]

21. Yapi, R.B.; Hürlimann, E.; Houngbedji, C.A.; Ndri, P.B.; Silue, K.D.; Soro, G.; Kouame, F.N.; Vounatsou, P.; Fürst, T.; N’Goran, E.K.; et al. Infection and co-infection with helminths and Plasmodium among school children in Côte d'Ivoire: Results from a national cross-sectional survey. PLoS Negl. Trop. Dis. 2014, 8, e2913. [CrossRef]

22. Tapajós, R.; Castro, D.; Melo, G.; Balogun, S.; James, M.; Pessoa, R.; Almeida, A.; Costa, M.; Pinto, R.; Albuquerque, B.; et al. Malaria impact on cognitive function of children in a peri-urban community in the Brazilian Amazon. Malar. J. 2019, 18, 173. [CrossRef]

23. Sokhna, C.; Le Hesran, J.Y.; Mbaye, P.A.; Akiana, J.; Camara, P.; Diop, M.; Ly, A.; Druilhe, P. Increase of malaria attacks among children presenting concomitant infection by Schistosoma mansoni in Senegal. Malar. J. 2004, 3, 43. [CrossRef] [PubMed]

24. Nacher, M.; Gay, F.; Singhasivanon, P.; Krudsood, S.; Treeprasertsuk, S.; Mazier, D.; Vouldoukis, I.; Looareesuwan, S. Ascaris lumbricoides infection is associated with protection from cerebral malaria. Parasite Immunol. 2000, 22, 107-113. [CrossRef] [PubMed]

25. Mitchell, A.J.; Hansen, A.M.; Hee, L.; Ball, H.J.; Potter, S.M.; Walker, J.C.; Hunt, N.H. Earlycy tokine production is associated with protection from murine cerebral malaria. Infect. Immun. 2005, 73, 5645-5653. [CrossRef]

26. Helmby, H.; Bickle, Q. Immune modulation by helminth infections. Parasite Immunol. 2006, 28, 479-481. [CrossRef] [PubMed]

27. Turner, J.D.; Faulkner, H.; Kamgno, J.; Cormont, F.; Van Snick, J.; Else, K.J.; Grencis, R.K.; Behnke, J.M.; Boussinesq, M.; Bradley, J.E. Th2 cytokines are associated with reduced worm burdens in a human intestinal helminth infection. J. Infect. Dis. 2003, 188, 1768-1775. [CrossRef]

28. Pierrot, C.; Adam, E.; Hot, D.; Lafitte, S.; Capron, M.; George, J.D.; Khalife, J. Contribution of T cells and neutrophils in protection of young susceptible rats from fatal experimental malaria. J. Immunol. 2007, 178, 1713-1722. [CrossRef] 
29. Nacher, M.; Singhasivanon, P.; Traoe, B.; Vannaphan, S.; Gay, F.; Chindanond, D.; Francois, J.; Mazier, D.; Looareesuwan, S. Helminths infection are associated with protection from cerebral malaria and increased nitrogen derivatives concentrations in Thailand. Am. J. Trop. Med. Hyg. 2002, 66, 304-309. [CrossRef]

30. Yaman, F.M.; Mokela, D.; Genton, B.; Rockett, K.A.; Alpers, M.P.; Clark, I.A. Association between serum levels of reactive nitrogen intermediates and coma in children with cerebral malaria in Papua New Guinea. Trans. R. Soc. Trop. Med. Hyg. 1996, 90, 270-273. [CrossRef]

31. Murray, M.J.; Murray, A.B.; Murray, M.B.; Murray, C.J. Parotid enlargement, forehead edema and suppression of malaria as nutritional consequences of ascariasis. Am. J. Clin. Nutr. 1977, 30, 2117-2121. [CrossRef]

32. Murray, J.; Murray, A.; Murray, M.; Murray, C. The biological suppression of malaria: An ecological and nutritional interrelationship of a host and two parasites. Am. J. Clin. Nutr. 1978, 31, 1363-1366. [CrossRef]

33. Nacher, M.; Singhasivanon, P.; Traore, B.; Dejvorakul, S.; Phumartanaprapin, W.; Looareesuwan, S.; Gay, F. Hookworm infection is associated with decreased body temperature during mild Plasmodium falciparum malaria. Am. J. Trop. Med. Hyg. 2001, 65, 131-137. [CrossRef] [PubMed]

34. Hesran, J.; Akiana, J.; Ndiaye, E.I.; Dia, M.; Senghor, P.; Konate, L. Severe malarial attack is associated with high prevalence of Ascaris lumbricoides infection among children in rural Senegal. Trans. R. Soc. Trop. Med. Hyg. 2004, 98, 397-399. [CrossRef] [PubMed]

35. Shapiro, A.E.; Tukahebwa, E.M.; Kasten, J.; Clarke, S.E.; Magnussen, P.; Olsen, A.; Kabatereine, N.B.; Ndyomugyenyi, R.; Brooker, S. Epidemiology of helminths infections and their relationship to clinical malaria in southwest Uganda. Trans. R. Soc. Trop. Med. Hyg. 2005, 99, 18-24. [CrossRef] [PubMed]

36. Kelly-Hope, L.A.; Diggle, P.J.; Rowlingson, B.S.; Gyapong, J.O.; Kyelem, D.; Coleman, M.; Thomson, M.C.; Obsomer, V.; Lindsay, S.W.; Hemingway, J.; et al. Negative spatiala ssociation between lymphatic filariasis and malaria in West Africa. Trop. Med. Int. Health 2006, 11, 129-135. [CrossRef] [PubMed]

37. Nacher, M.; Sighasivanon, P.; Yimsamran, S.; Manibunyong, W.; Thanyavanich, N.; Wuthisen, P.; Looareesuwan, S. Intestinal helminths infection are associated with increased incidence of Plasmodium falciparum malaria in Thailand. J. Parasitol. 2002, 88, 55-58. [CrossRef]

38. Mutapi, F.; Ndhlovn, P.D.; Hagan, P.; Woolhouse, M.E. Anti Schistosome antibody responsesin children coinfected with malaria. Parasite Immunol. 2000, 22, 207-208. [CrossRef]

39. Diallon, T.O.; Remoue, F.; Schacht, A.M.; Charrier, N.; Dompnier, J.P.; Pillet, S.; Garraud, O.; N’Diaye, A.A.; Capron, M.; Riveau, G. Schistosomiasis coinfection in humans influencesin flammatory markers in uncomplicated Plasmodium falciparum malaria. Parasite Immunol. 2004, 26, 365-369. [CrossRef]

40. MOOSE (Meta-analyses Of Observational Studies in Epidemiology) Checklist. A Reporting Checklist for Authors, Editors, and Reviewers of Meta-analyses of ObservationalStudies. Available online: https://www.elsevier.com/data/promis_misc/ISSM_ MOOSE_Checklist.pdf (accessed on 6 August 2020).

41. Moher, D.; Liberati, A.; Tetzlaff, J.; Altman, D.G.; Prisma Group. Preferred reporting items for systematic reviews and metaanalyses: The PRISMA statement. PLoS Med. 2009, 6, e1000097. [CrossRef]

42. The Joanna Briggs Institute Critical Appraisal Tools for Use in JBI Systematic Reviews Checklist for Prevalence Studies. Available online: http:/ /joannabriggs.org/research/critical-appraisal-tools.html (accessed on 3 July 2020).

43. Rendina-Gobioff, G. Detecting Publication Bias in Random Effects Meta-Analysis: An Empirical Comparison of Statistical Methods. Graduate Thesis, University of South Florida, Tampa, FL, USA, 2006. Available online: http: / / scholarcommons.usf. edu/etd/2671 (accessed on 12 October 2020).

44. Abay, S.M.; Tilahun, M.; Fikrie, N.; Habtewold, A. Plasmodium falciparum and Schistosoma mansoni coinfection and the side benefit of artemether-lumefantrine in malaria patients. J. Infect. Dev. Ctries. 2013, 7, 468-474. [CrossRef]

45. Degarege, A.; Animut, A.; Legesse, M.; Erko, B. Malaria severity status in patients with soil-transmitted helminth infections. Acta Trop. 2009, 112, 8-11. [CrossRef]

46. Tuasha, N.; Hailemeskel, E.; Erko, B.; Petros, B. Comorbidity of intestinal helminthiases among malaria outpatients of Wondo Genet health centers, southern Ethiopia: Implications for integrated control. BMC Infect. Dis. 2019, 19, 659. [CrossRef] [PubMed]

47. Degarege, A.; Animut, A.; Legesse, M.; Erko, B. Malaria and helminth co-infections in outpatients of Alaba Kulito Health Center, southern Ethiopia: A cross sectional study. BMC Res. Notes 2010, 3, 143. [CrossRef] [PubMed]

48. Getachew, M.; Tafess, K.; Zeynudin, A.; Yewhalaw, D. Prevalence Soil Transmitted Helminthiasis and malaria co-infection among pregnant women and risk factors in Gilgel Gibe dam Area, Southwest Ethiopia. BMC Res. Notes 2013, 6, 263. [CrossRef] [PubMed]

49. Degarege, A.; Animut, A.; Legesse, M.; Medhin, G.; Erko, B. Malaria and helminth co-infection and nutritional status of febrile patients in Southern Ethiopia. J. Infect. Public Health 2014, 7, 32-37. [CrossRef]

50. Fanuael, W.; Asrat, H.; Nigus, F. Malaria and Intestinal Helminth Coinfections among Acute Febrile Outpatients in Arbaminch Health Center, Southern Ethiopia. Available online: https://www.escmid.org/escmid_publications/escmid_elibrary/material/ ?mid=10184 (accessed on 26 September 2020).

51. Alemu, A.; Shiferaw, Y.; Ambachew, A.; Hamid, H. Malaria helminth co-infections and their contribution for aneamia in febrile patients attending Azzezo health center, Gondar, Northwest Ethiopia: A cross sectional study. Asian Pac. J. Trop. Med. 2012, 5, 803-809. [CrossRef]

52. Getie, S.; Wondimeneh, Y.; Getnet, G.; Workineh, M.; Worku, L.; Kassu, A.; Moges, B. Prevalence and clinical correlates of Schistosoma mansoni co-infection among malaria infected patients, Northwest Ethiopia. BMC Res. Notes 2015, 8, 480. [CrossRef] 
53. Deribew, K.; Tekeste, Z.; Petros, B. Urinary schistosomiasis and malaria associated anemia in Ethiopia. Asian Pac. J. Trop. Biomed. 2013, 3, 307-310. [CrossRef]

54. Masoud, N.S. Plasmodium and Soil-Transmitted Helminth Co-Infection: Epidemiological Interaction and Impact among Children Living in Endemic Areas of Bagamoya, Coastal Region of Tanzania. Doctoral Dissertation, University of Basel, Basel, Switzerland, 2018. Available online: http:/ / edoc.unibas.ch/diss/DissB_11506 (accessed on 15 October 2020).

55. Egwunyenga, A.O.; Ajayi, J.A.; Nmorsi, O.P.; Duhlinska-Popova, D.D. Plasmodium/intestinal helminth co-infections among pregnant Nigerian women. Memórias Inst. Oswaldo Cruz 2001, 96, 1055-1059. [CrossRef]

56. Babamale, O.A.; Ugbomoiko, U.S.; Heukelbach, J. High prevalence of Plasmodium falciparum and soil-transmitted helminth co-infections in a periurban community in Kwara State, Nigeria. J. Infect. Public Health 2018, 11, 48-53. [CrossRef]

57. Yatich, N.J.; Funkhouser, E.; Ehiri, J.E.; Agbenyega, T.; Stiles, J.K.; Rayner, J.C.; Turpin, A.; Ellis, W.O.; Jiang, Y.; Williams, J.H.; et al. Malaria, intestinal helminths and other risk factors for stillbirth in Ghana. Infect. Dis. Obstet. Gynecol. 2010, $2010,350763$. [CrossRef]

58. Ezeamama, A.E.; Mc Garvey, S.T.; Acosta, L.P.; Zierler, S.; Manalo, D.L.; Wu, H.W.; Kurtis, J.D.; Mor, V.; Olveda, R.M.; Friedman, J.F. The synergistic effect of concomitant schistosomiasis, hookworm, and trichuris infections on children's anemia burden. PLoS Negl. Trop. Dis. 2008, 2, e245. [CrossRef] [PubMed]

59. Mireku, M.O. The Effects of Anemia during Pregnancy and Its Risk Factors on the Cognitive Development of One-Year-Old Children in Benin. Ph.D. Thesis, Université Pierre et Marie Curie-Paris 6, Paris, France, 2016. Available online: https: / / tel.archives-ouvertes.fr/tel-01401973 (accessed on 8 July 2020).

60. Righetti, A.A.; Glinz, D.; Adiossan, L.G.; Koua, A.Y.; Niamké, S.; Hurrell, R.F.; Weg Müller, R.; N'Goran, E.K.; Utzinger, J. Interactions and potential implications of Plasmodium falciparum-hookworm coinfection in different age groups in south-central Côte d'Ivoire. PLoS Negl. Trop. Dis. 2012, 6, e1889. [CrossRef] [PubMed]

61. Malta, D.C.; Goulart, E.M.; Costa, M.F. Nutritional status and socioeconomic factors associated with failure in school: A prospective study of first grade students in Belo Horizonte, Brazil. Cad. Saúde Pública 1998, 14, 157-164. [CrossRef] [PubMed]

62. dos Santos, L.M.; dos Santos, D.N.; Bastos, A.C.; Assis, A.M.; Prado, M.S.; Barreto, M.L. Determinants of early cognitive development: Hierarchical analysis of a longitudinal study. Cad. Saúde Pública 2008, 24, 427-437. [CrossRef] [PubMed]

63. Benzecry, S.G.; Alexandre, M.A.; Vítor -Silva, S.; Salinas, J.L.; de Melo, G.C.; Marinho, H.A.; Paes, A.T.; de Siqueira, A.M.; Monteiro, W.M.; Lacerda, M.V.; et al. Micronutrient deficiencies and Plasmodium vivax malaria among children in the Brazilian Amazon. PLoS ONE 2016, 11, e0151019. [CrossRef]

64. Kotepui, M.; Kotepui, K.U.; Milanez, G.D.; Masangkay, F.R. Global prevalence and mortality of severe Plasmodium malariae infection: A systematic review and meta-analysis. Malar. J. 2020, 19, 1-3. [CrossRef]

65. Deress, T.; Girma, M. Plasmodium falciparum and Plasmodium vivax Prevalence in Ethiopia: A Systematic Review and Meta-Analysis. Malar. Res. Treat. 2019, 2019, 7065064. [CrossRef]

66. Kotepui, M.; Kotepui, K.U.; Milanez, G.D.; Masangkay, F.R. Prevalence and risk factors related to poor outcome of patients with severe Plasmodium vi vax infection: A systematic review, meta-analysis, and analysis of case reports. BMC Infect. Dis. 2020, 20, 363. [CrossRef]

67. Aron, J.L.; May, R.M. The population dynamics of malaria. In The Population Dynamics of Infectious Diseases: Theory and Applications; Springer: Boston, MA, USA, 1982; pp. 139-179.

68. Kotepui, M.; Kotepui, K.U.; Milanez, G.D.; Masangkay, F.R. Plasmodium spp. mixed infection leading to severe malaria: A systematic review and meta-analysis. Sci. Rep. 2020, 10, 1-12. [CrossRef]

69. Karshima, S.N. Prevalence and distribution of soil-transmitted helminth infections in Nigerian children: A systematic review and meta-analysis. Infect. Dis. Poverty 2018, 7, 69. [CrossRef]

70. Zibaei, M.; Nosrati, M.R.; Shadnoosh, F.; Houshmand, E.; Karami, M.F.; Rafsanjani, M.K.; Majidiani, H.; Ghaffarifar, F.; Cortes, H.C.; Dalvand, S.; et al. Insights into hookworm prevalence in Asia: A systematic review and meta-analysis. Trans. R. Soc. Trop. Med. Hyg. 2020, 114, 141-154. [CrossRef]

71. Hailegebriel, T.; Nibret, E.; Munshea, A. Prevalence of Soil-Transmitted Helminth Infection among School-Aged Children of Ethiopia: A Systematic Review and Meta- Analysis. Infect. Dis. Res. Treat. 2020, 13, 1178633720962812.

72. Taghipour, A.; Ghodsian, S.; Jabbari, M.; Olfatifar, M.; Abdoli, A.; Ghaffarifar, F. Global prevalence ofintestinal parasitic infections and associated risk factors in pregnant women: A systematic review and meta-analysis. Trans. R. Soc. Trop. Med. Hyg. 2020, 1-14. [CrossRef]

73. Afroz, S.; Debsarma, S.; Dutta, S.; Rhaman, M.M.; Mohsena, M. Prevalence of helminthic infestations among Bangladeshi rural children and its trend since mid-seventies. IMC J. Med. Sci. 2019, 13, 004. [CrossRef]

74. Leta, G.T.; Mekete, K.; Wuletaw, Y. National mapping of soil-transmitted helminth and schistosome infections in Ethiopia. BMC Parasites Vectors 2020, 13, 437. [CrossRef]

75. Silver, Z.A.; Kaliappan, S.P.; Samuel, P.; Venugopal, S.; Kang, G.; Sarkar, R.; Ajjampur, S.S. Geographical distribution of soil transmitted helminths and the effects of community type in South Asia and South East Asia-A systematic review. PLoS Negl. Trop. Dis. 2018, 12, e0006153. [CrossRef] 